\title{
Effect of Ramadan fasting on glucose level, lipid profile, HbA1c and uric acid among medical students in Karachi, Pakistan
}

Nazeer Khan ', Abdur Rasheed ${ }^{2}$, Hassaan Ahmed ${ }^{2}$, Faiza Aslam ${ }^{2}$ and Fatima Kanwal ${ }^{2}$

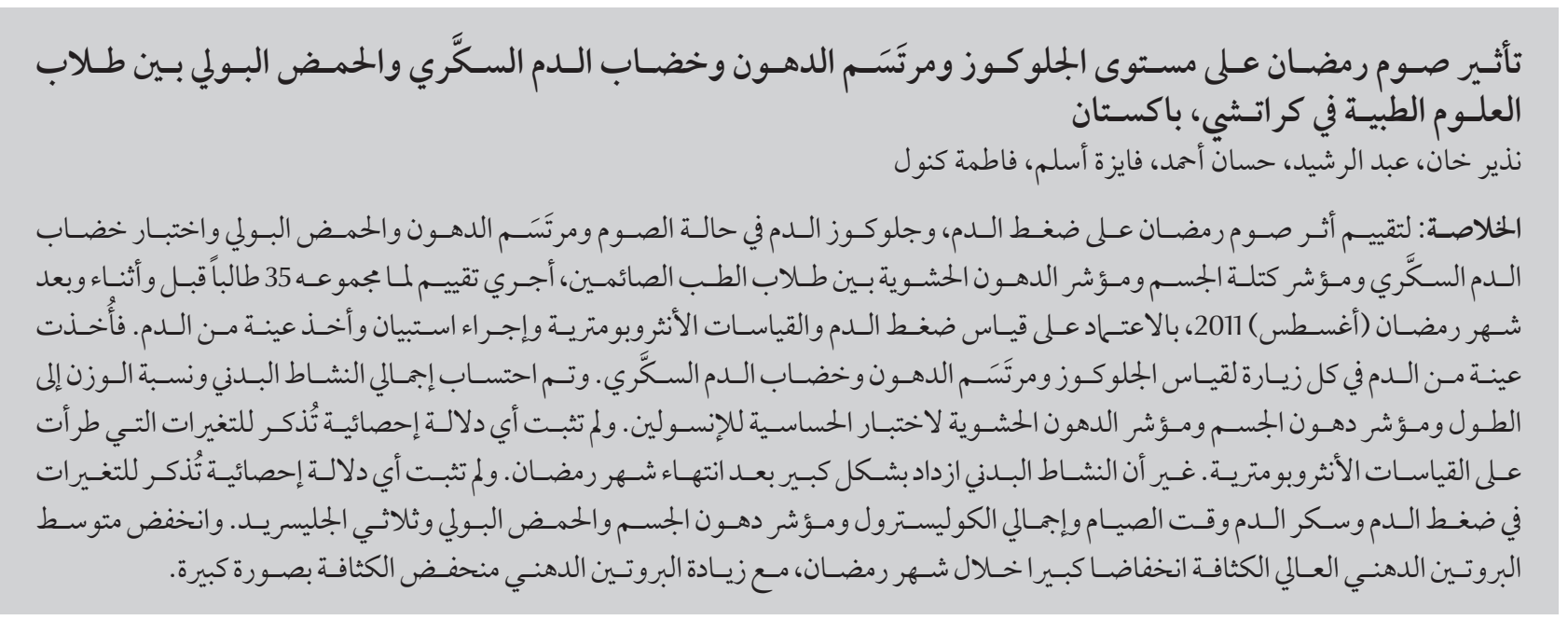

ABSTRACT To assess the effect of Ramadan fasting on blood pressure, fasting glucose, lipid profile, uric acid, $\mathrm{HbA1c}$, body mass index, body adiposity index and visceral adiposity index among fasting medical students, 35 students were recorded before, during and after Ramadan (August) 2011, for their blood pressure, anthropometric measurements, questionnaire response and blood sample. A blood sample was taken at each visit for glucose, lipid profile and HbA1c. Total physical activity, weight-to-height ratio, body adiposity index and visceral adiposity index were calculated for insulin sensitivity. Changes in anthropometric measurements were not statistically significant. However, physical activities increased significantly after Ramadan. Changes in blood pressure, fasting blood sugar, total cholesterol, HbA1c, uric acid and triglyceride were not statistically significant. Mean high density lipoprotein decreased significantly in Ramadan, while low density lipoprotein increased significantly.

Effets du jeûne du Ramadan sur la glycémie, le profil lipidique, I'HbA1c et l'acide urique d'étudiants en médecine à Karachi, Pakistan

RÉSUMÉ Afin de mesurer les effets du jeûne du Ramadan sur la tension artérielle, la glycémie à jeun, le profil lipidique, l'acide urique, I'hémoglobine glyquée (HbA1c), l'indice de masse corporelle, l'indice d'adiposité corporelle et l'indice d'adiposité viscérale d'étudiants en médecine pratiquant le jeûne, 35 étudiants ont été évalués avant, pendant et après Ramadan (août) 2011. Leur pression artérielle a été contrôlée, les mesures anthropométriques ont été prises, un questionnaire leur a été remis et des analyses de sang ont été réalisées. Des prélèvements sanguins ont été effectués à chaque visite pour mesurer le glucose, le profil lipidique et I'HbA1c. L'activité physique totale, le rapport poids-taille, l'indice d'adiposité corporelle et l'indice d'adiposité viscérale ont été calculés pour déterminer la sensibilité à l'insuline. Les changements au niveau des mesures anthropométriques n'étaient pas statistiquement significatifs. En revanche, l'activité physique connaissait une nette augmentation après le Ramadan. Les changements au niveau de la pression artérielle, de la glycémie à jeun, du cholestérol total, de l'HbAlc, de l'acide urique et des triglycérides n'étaient pas significatifs d'un point de vue statistique. Les lipoprotéines de haute densité moyennes baissaient significativement pendant le Ramadan, au contraire des lipoprotéines de basse densité qui augmentaient considérablement.

'Jinnah Sindh Medical University, Karachi, Pakistan (Correspondence to: N. Khan:nazeerkhan54@gmail.com). ${ }^{2 D o w}$ University of Health Sciences, Karachi, Pakistan.

Received: 01/06/16; accepted: 19/10/16 


\section{Introduction}

During Ramadan, fasting is obligatory for all adult Muslims from dawn to dusk except for people who fulfil certain conditions. Since the lunar year is about 11 days shorter than solar year, the month of Ramadan rotates in all the 4 seasons, consequently the duration of fasting varies from 11 to 18 hours in tropical countries (1). The approximate population of Muslims aged 15 years and older is 1061 million (2); most refrain from food, drink, smoking and sexual activities from dawn to dusk during Ramadan and adjust these activities to between sunset and dawn. A special prayer (traweeh) is also performed during this month in each night. The changes in meal frequency, meal times and performing prayers modify sleeping pattern, and thus may affect the health of the fasting person.

Many studies have been conducted on the effects of fasting, the majority of which are related to patients who have diabetes and management of their disease $(3-10)$. However, other studies have been conducted on non-diabetes patients and healthy subjects $(11-16)$. Some studies focused on the effects of Ramadan fasting on young university students among Arab and Iranian students (1,17-24). The eating habits and other physical activities of the Pakistani population during Ramadan may differ compared with the Muslim populations of Arab and other countries, therefore, there is a possibility that the effect of Ramadan fasting could be different for Pakistani university students. Only a few clinical studies have been conducted on the Ramadan fasting effects on young Pakistanis (25-27) and others are related to diabetes patients (3-5). As far as we know, only 1 recent study showed the biochemical changes of Ramadan fasting among healthy young Pakistani adults (27). Further studies are needed to strengthen those results.

Hence, the objective of the study is to assess the effect of Ramadan fasting on blood pressure, fasting glucose, cholesterol, triglyceride, high density lipid, low density lipid, uric acid, HbAlc, weight, body mass index, body adiposity index and visceral adiposity index among fasting medical students.

\section{Methods}

The sample size for the study was calculated using the change in high density lipoprotein (HDL) value (mean and standard deviation) from before and after Ramadan (21). With 95\% confidence interval and $80 \%$ power of the test, the sample size was calculated as 33; thus 35 healthy medical students were invited to participate in this study. The students were selected by convenience sampling from 4 th year students of the Bachelor of Medicine and Bachelor of Surgery programme at Dow Medical College, Dow University of Health Sciences, a public medical university in Karachi. The study was conducted in $1432 \mathrm{Hijri}, 2011$ in the Gregorian calendar. The month of Ramadan was in August during that year and fasting duration was about 15 hours. Weather was cloudy most of the time with a breeze and maximum temperature was about $31-34^{\circ} \mathrm{C}$.

The study was approved by the Institutional Review Board of Dow University of Health Sciences. Inclusion criteria were: young, healthy medical students of both sexes who had the intention to fast for $\geq 20$ days in the forthcoming Ramadan. Exclusion criteria were: pregnancy, those diagnosed with renal failure, hepatic impairment, diabetes mellitus, hypertension, hyperlipidaemia, thyroid problems or cardiovascular diseases and users of weight reducing agents. The participants were requested to visit the project office 3 times: in the last 10 days of Shaban (the month before Ramadan), 22-30 July2011; in the last 10 days of Ramadan, 20-29 August 2011; and in the last 10 days of Shawwal (the month after
Ramadan), 19-27 September 2011, for blood pressure and anthropometric measurements and an interview for a questionnaire. The blood samples were collected during the morning after 12 hours fasting in Shaban and Shawwal and about 12 hours after sahure (morning meal) in Ramadan at the collection points of the pathology laboratory. A $10 \mathrm{~mL}$ sample was taken from the antecubital vein and was centrifuged for 5 minutes for serum separation. Blood analysis was completed within 2 hours of collection, using the Hitachi 902 auto-analyser, which uses Diasoria kits, and was handled by trained personnel at the Diagnostic Research and Reference Laboratories. All samples were analysed for glucose, cholesterol, triglyceride, uric acid, high density lipoprotein cholesterol (HDL-C), low density lipoprotein cholesterol (LDL-C) and $\mathrm{HbAlc}$. In each visit a questionnaire was administered to each participant for demographic information, systemic diseases, physical activities and sleeping habits. The questionnaire was adapted from the studies conducted by Khan et al. $(4,5)$ with some modifications. The questionnaire was in English language. Since the respondents were 4 th year medical students, there was no need for translation into a local language. The number of days the participants had fasted during the Ramadan period and number of days Taraweeh prayers were performed was recorded in the last visit. Along with the interview, blood pressure was measured 2 times in a sitting position. Height, weight, waist and hip measurements were also taken. Information on intensity, duration and frequency of exercise was collected to measure the physical activity indices of the participants. Intensity of exercise was classed as: high intensity activities, including running, swimming and fast cycling; moderate intensity activities, including cycling, light jogging, brisk walking, and cricket; and low intensity activities, including golfing and normal walking. Metabolic energy turnover 
(MET) value assigned to high, moderate and low intensity activities was 7.5, 6.0 and 2.5 respectively. One MET value is equivalent to the energy outflow at rest or approximately $3.5 \mathrm{~mL}$ oxygen utilized $/ \mathrm{kg}$ body weight $/ \mathrm{min}$. Total physical activity is defined as physical activity $=$ MET value $\times$ duration (min per session) $\times$ frequency (activity per week).

A participant was categorized as active if the physical activity value was > 600 MET min per week, otherwise he/she was classified as inactive (5).

Recently, new indices have been introduced to measure obesity and insulin sensitivity $(28,29)$. These new indices are waist-to-height ratio (WHtR), body adiposity index (BAI) and sex-specific visceral adiposity index (VAI). It has been shown that these indices, especially VAI, have comparatively higher specificity and sensitivity than the usual measurements like body mass index (BMI) and waist circumference for cardiometabolic risk assessment. They are defined as follows.

\section{$\mathbf{W H t R}=$ Waist $(\mathrm{cm})$ Height $(\mathrm{cm})$ \\ $\mathbf{B A} \mathbf{I}=$ $\frac{\operatorname{Hip}(\mathrm{cm})}{\text { Height }^{1.5}(\mathrm{~m})}-18$ \\ VAI $($ males $)=$

$$
\begin{gathered}
\left(\frac{\text { Waist }(\mathrm{cm})}{39.68+(1.88 \times B M l)}\right) \times\left(\frac{\mathrm{TG}(\mathrm{mmol} / \mathrm{l})}{1.03}\right) \\
\times\left(\frac{1.31}{H D L(\mathrm{mmol} / \mathrm{l})}\right)
\end{gathered}
$$

\section{VAI $($ females $)=$}

$$
\begin{gathered}
\left(\frac{\text { Waist }(\mathrm{cm})}{36.58+(1.89 \times B M l)}\right) \times\left(\frac{\mathrm{TG}(\mathrm{mmol} / \mathrm{l})}{0.81}\right) \\
\times\left(\frac{1.52}{H D L(\mathrm{mmol} / \mathrm{l})}\right)
\end{gathered}
$$

assuming VAI = 1 in healthy non-obese subjects with normal adipose distribution and normal triglyceride (TG) and HDL levels
Data were entered and analysed using SPSS, version 21. Since the same subjects were used 3 times for collection of data, repeated measures analysis of variance (ANOVA) tests were employed with visits as within subjects and active/inactive and number of fasting days as covariates to analyse mean values of anthropometric measurements (weight, hips, waist, hips and waist ratio, waist and height ratio, and BMI), blood pressure, glucose level, cholesterol, triglyceride, HDL, LDL, uric acid BAI and VAI during the 3 visits. Due to the small sample size, the power of the statistical tests did not attain the acceptable level ( $\geq 80 \%)$. Nevertheless, the sample size was calculated using $80 \%$ power. Therefore the non-parametric Freidman (K-related samples) test was employed later. However, the parametric repeated measures design (Freidman) ANOVA test does not have an option for covariate analysis along with related sample analysis, therefore the $P$-values for covariates were obtained from the parametric test.

\section{Results}

Out of 35 students, 18 (51.4\%) were males. Only 2 students were current smokers, and 6 were passive smokers (living in a smoking environment). Mean age of the students was 21.66 [standard deviation (SD) 0.68; Range (R): 21-23] years. Mean height of the participants was 167.8 (SD 10.0; $R$ : $152-189) \mathrm{cm}$ and mean duration of fasting was 25 (SD 3.2; R: 20-30) days.

Table 1 describes the mean values for anthropometric observations for the 35 participants. The mean weight fell from 60.49 (SD 14.74) $\mathrm{kg}$ in visit 1 to 60.17 (SD 14.52) kg in visit 3. However, the difference was not statistically significant. However, the effect of number of days of fasting on weight reduction was statistically significant $(P=0.013)$. Due to reduction in mean weight, the mean BMI also fell, from 21.33 (SD 3.99) $\mathrm{kg} / \mathrm{m}^{2}$ in visit 1 to 21.25 (SD 3.94$) \mathrm{kg} /$ $\mathrm{m}^{2}$ in visit 3 . The mean waist:hip ratio also decreased continuously, but not statistically significantly. However, the number of days of fasting significantly affected this ratio $(P=0.001)$. The active/inactive covariate did not show any significant difference in any of the anthropometric variables. The mean activity index reduced noticeably but not significantly from visit 1 to visit 2 and then increased significantly in visit 3 .

Table 2 shows the mean values for the blood pressure and biochemical analysis of the participants' blood samples. Mean systolic blood pressure increased, but not statistically significantly. However, the number of days of fasting showed a significant effect $(P$ $=0.016)$. Mean triglyceride level decreased from $87.76(\mathrm{SD} 37.87) \mathrm{mg} / \mathrm{dL}$ in visit 1 to $79.82(\mathrm{SD} 34.54) \mathrm{mg} / \mathrm{dL}$ in visit 2 and then increased to 83.61 (SD $34.50) \mathrm{mg} / \mathrm{dL}$ in visit 3. Even though the mean values were quite different in the 3 visits, none of the differences were statistically significant due to the high standard deviations. The number of fasting days did not show any significant effect on fasting glucose, cholesterol or triglyceride levels $(P>0.05)$. Mean value of HDL decreased significantly from 55.88 in visit 1 to 49.82 in visit $2(P<0.05)$ and further decreased to 48.70 in visit 3 , but this was not statistically significant. Number of fasting days showed a significant effect in the change in mean HDL values $(P=0.028)$. Mean LDL increased significantly from 87.36 in visit 1 to 95.03 in visit $2(P<0.05)$ and decreased significantly to 87.56 in visit 3. There was no significant change in the mean $\mathrm{HbAlc}$ value. Lastly, the mean value of uric acid of 4.75 in visit 1 increased to 5.35 in visit 2 , but decreased nonsignificantly to 5.17 in visit 3 . However, number of fasting days significantly affected the change in uric acid level $(P$ $=0.004)$. Activity $/$ inactivity as covariate did not show any significant effect in any of the parameters (Table 2). 


\begin{tabular}{|c|c|c|c|c|c|c|c|c|}
\hline \multirow[t]{2}{*}{ Variable } & \multicolumn{2}{|c|}{ Visit 1} & \multicolumn{2}{|c|}{ Visit 2} & \multicolumn{2}{|c|}{ Visit 3} & \multicolumn{2}{|c|}{ Effect of covariates $\boldsymbol{P}$-value } \\
\hline & Mean & SD & Mean & SD & Mean & SD & Fasting days & Active/ inactive \\
\hline Weight (kg) & 60.49 & $14.74^{\mathrm{a}}$ & 60.46 & $15.02^{\mathrm{a}}$ & 60.17 & $14.52^{\mathrm{a}}$ & 0.013 & 0.849 \\
\hline $\mathrm{BMI}\left(\mathrm{kg} / \mathrm{m}^{2}\right)$ & 21.33 & $3.99^{\mathrm{a}}$ & 21.27 & $4.03^{\mathrm{a}}$ & 21.25 & $3.94^{\mathrm{a}}$ & 0.284 & 0.626 \\
\hline Waist (cm) & 79.90 & $10.18^{\mathrm{a}}$ & 79.74 & $10.33^{\mathrm{a}}$ & 79.42 & $10.87^{\mathrm{a}}$ & 0.012 & 0.216 \\
\hline Hips (cm) & 95.56 & $9.73^{\mathrm{a}}$ & 96.12 & $7.69^{\mathrm{a}}$ & 96.19 & $8.57^{\mathrm{a}}$ & 0.370 & 0.345 \\
\hline Waist:hip ratio & 0.84 & $0.07^{\mathrm{a}}$ & 0.83 & $0.07^{\mathrm{a}}$ & 0.82 & $0.07^{\mathrm{a}}$ & 0.001 & 0.397 \\
\hline Waist:height ratio & 0.48 & $0.05^{\mathrm{a}}$ & 0.48 & $0.05^{\mathrm{a}}$ & 0.47 & $0.06^{\mathrm{a}}$ & 0.093 & 0.966 \\
\hline Physical activity & 172.50 & $241.90^{\mathrm{a}}$ & 136.10 & $165.48^{\mathrm{a}}$ & 236.30 & $281.17^{b}$ & & \\
\hline
\end{tabular}

$B M I=$ body mass index

${ }^{a, b}$ Different superscripts denote difference between mean values is statistically significant.

\section{Discussion}

Although a number of studies have been conducted on university students in different countries for the effects of Ramadan fasting (1,17-24), few have been published from Pakistan (25-27), one of which discussed the biochemical effect of fasting on medical students (27). Therefore, there is a need to conduct more studies to strengthen the results. One of the limitations of our study was the inclusion of both sexes: during menstruation, females will not be fasting for some days, however, because the number of female students in public medical universities in Pakistan is overwhelming, to include only males in the study was not possible. However, we tried to get the sex ratio almost equal in this study so that the outcomes would not be skewed or unrepresentative because of missed fasting days among female students. Since all the students belonged to the 4th year of the MBBS programme, the age variation was very small and hence the effect of age was negligible. The study did not have a control group (not fasting), because it is not easy to get enough non-fasting medical students in the Pakistani culture.

Mean weight was reduced slightly in Ramadan in this study. A majority of studies showed a significant decrease in mean weight in Ramadan (16,18,2024) but this was recouped in Shawwal $(21,23)$. Shruthi et al. indicated that the decrease in weight during Ramadan could be due to a reduction in fluid intake and a decline in glycogen-bound water stores (24). Meals are taken during night-time only and are less frequent, and hence could affect calories and dietary consumption (20).

We found that body weight further reduced in Shawwal. This may be because participants have started heavy physical exercises in Shawwal to maintain their weight, and consequently reduced their weight further after Ramadan. The BMI reduced insignificantly simultaneously. Hip, waist and hip/ waist ratio also reduced in Ramadan and Shawwal from Shaban, but the changes were not significant. Fakhrzadeh et al. also showed that there was significant reduction in waist circumference among male Iranian students during Ramadan (22). Furthermore, Shruthi et al. also showed significant reduction in waist measurement and waist to hip ratio among Indian medical students in Ramadan (24). The mean BMI was little more than $21 \mathrm{~kg} / \mathrm{m}^{2}$ with low standard deviation in this study which indicates that most of the students were healthy with a normal BMI range. Hence Ramadan fasting did not affect their anthropometric measurements. We found a reduction of waist to height ratio in Ramadan and this continued in Shawwal. Shruthi et al. and Celik et al. also found a significant reduction for this ratio $(24,28)$. It is common practice that fasting subjects either stop physical exercises or at least reduce the duration significantly in Ramadan due to fear of thrust and dehydration and in Shawwal they start again with more zeal and enthusiasm. Al Hourani and Atoum showed that the number of young females who were involved in activity of level 6 and level 7 on the Physical Activity Level reduced their physical activity during Ramadan (20).

Systolic blood pressure (SBP) increased continuously but not significantly in Ramadan and in Shawwal. Fakhrzadeh et al. found negligible changes in SBP in seminary students during Ramadan (22). However, Mansi and Shruthi et al. found a significant reduction in SBP by the end of Ramadan (23,24). Diastolic blood pressure (DBP) also increased in Ramadan and continued in Shawwal. Fakhrzadeh et al. also found that DBP increased in Ramadan quite a bit, but this was not statistically significant (22). However, Mansi and Shruthi et al. reported the opposite results with a significant reduction in DBP during Ramadan $(23,24)$.

This study showed that fasting blood sugar decreased slightly in Ramadan and rebounded in the next month, Shawwal. A number of other studies also showed the same trend from Shaban to Ramadan $(19,22,23)$ and recovered after Ramadan $(17,19)$. However, some studies reported the opposite result: an increase in glucose level by the 


\begin{tabular}{|c|c|c|c|c|c|c|c|c|}
\hline \multirow[t]{2}{*}{ Variable } & \multicolumn{2}{|c|}{ Visit 1} & \multicolumn{2}{|c|}{ Visit 2} & \multicolumn{2}{|c|}{ Visit 2} & \multicolumn{2}{|c|}{ Effect of covariate $P$-value } \\
\hline & Mean & SD & Mean & SD & Mean & SD & Fasting days & Active/ inactive \\
\hline Systolic BP (mmHg) & 113.08 & $10.52^{\mathrm{a}}$ & 113.56 & $9.50^{\mathrm{a}}$ & 114.71 & $10.57^{\mathrm{a}}$ & 0.016 & 0.559 \\
\hline Diastolic BP (mmHg) & 74.71 & $7.08^{\mathrm{a}}$ & 75.94 & $6.92^{\mathrm{a}}$ & 76.14 & $7.38^{\mathrm{a}}$ & 0.424 & 0.587 \\
\hline Fasting blood sugar (mg/dL) & 88.79 & $9.10^{\mathrm{a}}$ & 87.2 & $6.35^{\mathrm{a}}$ & 89.09 & $9.72^{\mathrm{a}}$ & 0.966 & 0.081 \\
\hline Total cholesterol (mg/dL) & 161.48 & $33.70^{\mathrm{a}}$ & 160.21 & $27.82^{\mathrm{a}}$ & 150.51 & $26.05^{\mathrm{a}}$ & 0.424 & 0.111 \\
\hline Triglyceride (mg/dL) & 87.76 & $37.87^{\mathrm{a}}$ & 79.82 & $34.54^{\mathrm{a}}$ & 83.61 & $34.50^{\mathrm{a}}$ & 0.333 & 0.880 \\
\hline $\mathrm{HDL}(\mathrm{mg} / \mathrm{dL})$ & 55.88 & $13.73^{\mathrm{a}}$ & 49.82 & $10.09^{b}$ & 48.70 & $12.35^{\mathrm{b}}$ & 0.028 & 0.768 \\
\hline LDL (mg/dL) & 87.36 & $20.33^{\mathrm{a}}$ & 95.03 & $23.54^{b}$ & 87.56 & $19.82^{\mathrm{a}}$ & 0.574 & 0.46 \\
\hline $\mathrm{HbAlc}(\mathrm{mmol} / \mathrm{mol})$ & 5.21 & $0.36^{\mathrm{a}}$ & 5.31 & $0.39^{a}$ & 5.24 & $0.33^{\mathrm{a}}$ & 0.801 & 0.233 \\
\hline Uric acid (mg/dL) & 4.75 & $1.65^{\mathrm{a}}$ & 5.35 & $1.48^{\mathrm{a}}$ & 5.17 & $1.24^{\mathrm{a}}$ & 0.004 & 0.778 \\
\hline BAI & 26.18 & $5.25^{\mathrm{a}}$ & 26.40 & $4.85^{\mathrm{a}}$ & 26.50 & $4.74^{\mathrm{a}}$ & 0.797 & 0.457 \\
\hline VAI & 1.10 & $0.47^{\mathrm{a}}$ & 1.12 & $0.52^{\mathrm{a}}$ & 1.23 & $0.63^{\mathrm{a}}$ & 0.807 & 0.182 \\
\hline
\end{tabular}

$S D=$ standard deviation; $B P=$ blood pressure; $H D L=$ high density lipoprotein; $B A I=$ body adiposity index; $V A I=$ visceral adiposity index; $L D L=$ low density lipoprotein . ${ }^{a, b}$ Different superscripts denote difference between mean values is statistically significant.

end of Ramadan (22). The reduction in fasting blood sugar in Ramadan could be due to increased gluconeogenesis in the liver. This physiological activity is due to reduction in insulin concentration and the increase in glucagon and sympathetic activity (23). Total cholesterol level dropped noticeably, but not significantly in Shawwal from Shaban and Ramadan. Other studies reported that cholesterol level reduced in Ramadan $(22,23)$ and turned back in Shawwal $(21,23)$. However, some studies showed that cholesterol level increased during Ramadan (28). Mean TG level dropped from Shaban to Ramadan and then recouped in Shawwal. The same reduction has been observed in other studies $(20,22,23)$ as has the return in Shawwal $(21,23,28)$. Mean HDL decreased significantly in Ramadan in this study. Al-Hourani et al. and Ziaee et al. $(20,21)$ also showed a significant decrease in HDL during Ramadan, however other studies did not agree with this result $(22,23,28)$. This re-emphasizes the fact that number of days of fasting also affected mean HDL values. Mean LDL increased in Ramadan and then returned in Shawwal. Al-Hourani et al., Ziaee et al. and Celik also showed significant increase in LDL during Ramadan $(20,21,28)$. There were minor, but statistically insignificant increases in mean BAI and VAI during Ramadan, but Celik et al. did not agree with these findings (28).

A limitation of this study was that it did not explore the effects of calorie intake and sleeping pattern. These factors might provide a better understanding of the changes occurring in the biochemical and anthropometrical parameters. Our results indicate that there are conflicting findings regarding the effects of Ramadan on young adult university students, mainly due to the cultural and regional conduct of daily practices such as sleeping and eating habits among the different nationalities during the month of Ramadan. Ramadan fasting experience was not noted during the interview and it was assumed that all the participants had experienced fasting before. Since factors such as diet pattern, daily practices, sleep and physical activities, season of fasting, type of job, climate and geographical location, affect the biochemical and physiological of a fasting person, however, due to inadequate sample size and selection of participants by convenience sampling, the outcomes of our study should be read with caution. A multicentre study with standardized methodology would help to understand the changes of Ramadan fasting more extensively.

\section{Acknowledgements}

The authors are grateful to Drs Ayesha Maqsood, NajiaTulQasim, Muhammad Furqan Khan, Fatima Kanwal, Nida Jamil, Nafiisah B.M.H. Rajabalee, MadihaViqarUsmani, AnumEllahi, HumzaSaleemMaqbool, Mahrukh Naqvi, Ahsan Alam, Mahrukh Rasheed, Sheikh Rehman, Anas Ahmed, Sidra Karimi, AnamAftab, SumayyaAslam, Mariam Zia, Mohsin Zaidi, Faryal Ali, SundusJaved, Sana Javed and Rizwana Ahmed for data collection.

We are also grateful to Dow University of Health Sciences for the research grant to conduct this study.

Funding: The study was funded by the Research Facilitating Committee of Dow University of Health Sciences.

Competing interests: None declared. 
1. Al Hourani HM, Atoum MF, Akel S, Hijjawi N, Awawdeh S. Effects of Ramadan fasting on some haematological and biochemical parameters. Jordan J Biological Sci. 2009;2(3):103-8 (http://jjbs.hu.edu.jo/files/v2n3/1.pdf, accessed 8 February 2017).

2. Religious composition by country, 2010-2050. Washington, DC: Pew Research Center; 2015 (http://www.pewforum. org/2015/04/02/religious-projections-2010-2050, accessed 24 November 2015).

3. Ahmadani MY, Riaz M, Gul A, Waheed MI, Hydrie ZI, Hakeem R, Basit A. Clinical profile of fasting diabetic subjects during Ramadan. J Coll Physicians Surg Pak. 2007;17:446-7. PMID:17686367

4. Khan N, Khan MH, Shaikh MZ, Khanani MR. Effects of Ramadan fasting on glucose levels and serum lipid profile among Type 2 diabetic patients. Saudi Med J. 2010;31(11):1269-70. PMID:21063662

5. Khan N, Khan MH, Shaikh MZ, Khanani MR, Rasheed A. Effects of Ramadan fasting and physical activity on glucose levels and serum lipid profile among Type 2 Diabetic patients. Pak J Med Sci. 2012;28(1):91-6 (http://pjms.com.pk/index.php/pjms/ article/view/1712, accessed 8 February 2017).

6. Schweizer A, Halimi S, Dejager S. Experience with DPP-4 inhibitors in the management of patients with type 2 diabetes fasting during Ramadan. Vasc Health Risk Manag. 2014;10:1524. PMID:24391442

7. Norouzy A, Mojajeri SMR, Shakeri S, Yari F, Salory M, et al. Effect of Ramadan fasting on glycemic control in patients with Type 2 diabetes. J Endocrinol Invest. 2012;35:766-71. PMID:21986487

8. Siaw MY, Chew DE, Dalan R, Abdulshakoor SA, Othman N, Choo $\mathrm{CH}$, et al. Evaluating the effect of Ramadan fasting on Muslim patients with diabetes in relation to use of medication and lifestyle patterns: a prospective study. Int J Endocrinol. 2014;2014:308546 Epub. PMID:25435876

9. Salti I, Benard E, Detournay B, Bianchi-Biscay M, Le Brigand C, Voinet $\mathrm{C}$, et al. A population-based study of diabetes and its characteristics during the fasting month of Ramadan in 13 countries. Diabetes Care. 2004;27:2306-11. PMID:15451892

10. Paul AK, Khan MA, Fariduddin M. Effect of Ramadan fasting on anthropometric measures and metabolic profiles among Type 2 diabetic subjects. J Enam Med Coll. 2015;5(2):93-8.

11. Akbari A, Golshan A, Moojdekanloo M, Hashemian M. Does fasting in Ramadan ameliorate lipid profile? A prospective observational study. Pak J Med Sci. 2014;30(4):708-11. PMID:25097501

12. Chtourou H, Hammouda O, Chaouachi A, Chamari K, Souissi N. The effect of time-of-day and Ramadan fasting on anaerobic performances. Int J Sports Med. 2012;33:142-7. PMID:22318530

13. Ajabnoor GM, Bahijri S, Borai A, Abdulkhaliq AA, Al-Aama JY, Chrousos GP. Health impact of fasting in Saudi Arabia during Ramadan: association with disturbed circadian rhythm and metabolic and sleeping patterns. PLOS One. 2014;9(5):e96500. PMID:24810091

14. Cağlayan EK, Göçmen AY, Delibas N. Effects of long-term fasting on female hormone levels: Ramadan model. Clin Exp Obstet Gynecol. 2014;41(1):17-9. PMID:24707675
15. HadiKhafaji HAR, Al Suwaidi JM. Ramadan fasting and lipid profile. Effects of Ramadan fasting on health and athletic performance. Los Angeles: OMICS Group eBooks; 2013 (https:// www.esciencecentral.org/ebooks/effects-of-ramadan-fasting/ramadan-fasting-and-lipid-profile.php, accessed 8 February 2017).

16. Suriani I, Shamsuddin K, Khalib AL, Hazizi AS, Fadlan MO. The effect of Ramadan weight loss on body composition of overweight and obese Muslims in University Putra Malaysia. Inter J Public Health Clin Sc. 2015;2(1):61-8.

17. Lamri-Senhadji MY, El Kebir B, Belleville KJ, Bouchenak M. Assessment of dietary consumption and time-course of changes in serum lipids and lipoproteins before, during and after Ramadan in young Algerian adults. Singapore Med J. 2009:50:288-94. PMID:19352573

18. Ganoou JV, Caszo BA, Khalil KM, Abdullah SL, Knight VF, Bidin MZ. Effects of Ramadan fasting on glucose homeostasis and adiponectin levels in healthy adults. J Diabetes Metab Dis. 2015;14:55. PMID:26155596

19. Larijani B, Zahedi F, Sanjari M, Amini MR, Jalili RB, Adibi H, et al. The effect of Ramadan fasting on fasting serum glucose in healthy adults. Med J Malaysia. 2003;58(5):678-80. PMID:15190653

20. Al-Hourani HM, Atoum MF. Body composition, nutrient intake and physical activity patterns in young women during Ramadan. Singapore Med J. 2007;48 (10):906-10. PMID:17909674

21. Ziaee V, Razaei M, Ahmadinejad Z, Shaikh H, Yousefi R, Yarmohammadi L, et al. The changes of metabolic profile and weight during Ramadan fasting. Singapore Med J. 2006;47(5):409-14. PMID:16645692

22. Fakhrzadeh H, Larijani B, Sanjari M, Baradar-Jalili R, Amini MR. Effect of Ramadan fasting on clinical and biochemical parameters in healthy adults. Ann Saudi Med. 2003:23:223-6. PMID:16985327

23. Mansi EMS. Study the effects of Ramadan fasting on the serum glucose and lipid profile among healthy Jordanian students. Am J Appl Sc. 2007;4(8):565-9.

24. Shruthi B, Hassan A, Reddy BV. The effect of Ramadan fasting on the body composition, blood pressure, heart rate of healthy young adults. Inter J Recent Trends Sc Tech. 2013:8(1):31-5.

25. Subhan MMF, Siddiqui QA, Khan MN, Sabir S. Does Ramadan fasting affect expiratory flow rates in healthy subjects? Saudi Med J. 2006;27(11):1656-60. PMID:7106536

26. Siddiqui QA, Sabir S, Subhan MMF. The effect of Ramadan fasting on spirometry in healthy subjects. Respirology. 2005;10(4):525-8. PMID:16135179

27. Kiyani MM, Memon AR, Amjad MI, Ameer MR, Sadiq M, Mahmood T. Study of human biochemical parameters during and after Ramadan. J Relig Health. 2017 Feb;56(1):55-62. PMID:26149778.

28. Celik A, Saricicek E, Saricicek V, Sahin E, Ozdemir G, Bozkurt $S$, et al. Effect of Ramadan fasting on serum concentration of apelin-13 and new obesity indices in healthy adult men. Med SciMonit, 2014;20:337-42. PMID:24576923

29. Amato MC, Giordano C, Galla M, Criscimanna A, Vitabile S, Midiri M, et al. Visceral adiposity index, a reliable indicator of visceral fat function associated with cardiometabolic risk. Diabetes Care. 2010;33(4):920-2. PMID:20067971 